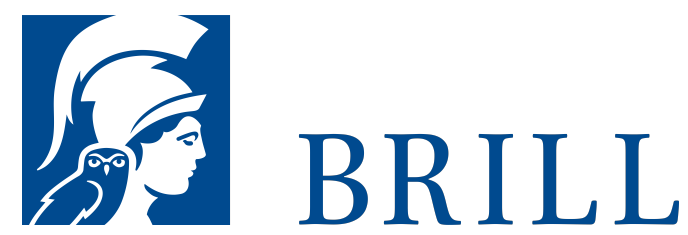

\title{
V-8 Ordinis quinti tomus octavus
}

\section{Enchiridion, Exomologesis}

Authors:Juliusz Domański, Jean-Pierre Massaut, André Godin, and Raymond Marcel

This volume, V-8, of the Erasmi Opera Omnia contains the Enchiridion, Erasmus' theological programme and the Exomologesis, his treatise on confession. These two texts are at the heart of Erasmian theology. This volume offers the first critical edition of these core texts with extensive commentaries and introductions.

Ce volume, V-8, des Erasmi Opera Omnia contient l'Enchiridion, le programme théologique d'Erasme, et l'Exomologesis, son traité sur la confession. Ces deux textes sont au coeur de la théologie érasmienne. Ce volume présente la première édition critique de ces textes fondamentaux avec de nombreux commentaires et présentations.

Readership

All those interested in Renaissance studies, Biblical scholarship, and the history of theology.

Ceux qui s'interessent dans les études de la Renaissance, études bibliques et l'histoire de la théologie.

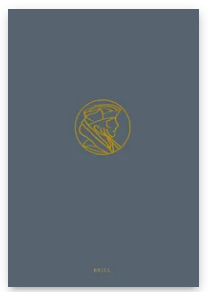

Pages: $460 \mathrm{pp}$ Language: English Subjects: General, History Publisher: Brill

Series:

Opera Omnia Desiderii Erasmi

- Erasmus, $<\mathrm{i}>$ Opera

Omnia</i>, Volume: V-8

E-Book (PDF)

Released online: 21 Sep 2016

ISBN: 978-9O-

O4-31359-O

Hardback

Publication date: 16 Sep 2016

ISBN: 978-90-

04-31358-3

List price

USD $\$ 206.00$ 
Juliusz Domański (1927) is Professor emeritus of Ancient, Medieval and Renaissance Philosophy at the University of Warsaw.

Jean-Pierre Massaut is Professor emeritus of the University of Liège, and an expert on religious and intellectual life in sixteenth-century France.

André Godin (1927) is Professor emeritus at the CNRS in Paris. He specialized in Erasmus and his reading of Origen, and in Jean Vitrier.

For more information see brill.com

\author{
Order information: Order online at brill.com \\ +44330 3330049 | customerservices@brill.com \\ Submission information: brill.com/authors
}

Titles published by Brill | Fink, Brill | mentis or Brill | Schöningh: +49(o)71 5413279216 | brill@brocom.de 